\title{
CURCUMINOIDS ANALYSIS IN CURCUMA MANGGA RHIZOMES
}

\author{
YUANDANI ${ }^{1,2 *}$, SRI YULIASMI ${ }^{3}$ \\ ${ }^{1}$ Department of Pharmacology, Faculty of Pharmacy, Universitas Sumatera Utara, Medan, Indonesia. ${ }^{2}$ Centre of Excellence for Green \\ Chitosan and Advanced Materials, Universitas Sumatera Utara, Medan, Indonesia. ${ }^{3}$ Department of Pharmaceutical Chemistry, Faculty of \\ Pharmacy, Universitas Sumatera Utara, Medan, Indonesia. Email: yuan_dani@yahoo.com
}

Received: 07 March 2018, Revised and Accepted: 25 March 2018

ABSTRACT

Objective: The current study was conducted to analyze the curcuminoid content in ethanol extract of Curcuma mangga.

Methods: The constituent of ethanol extract of C. mangga was determined using ultra-performance liquid chromatography (UPLC). The diluted solutions of the extracts and the reference standards were analyzed separately by the reversed-phase UPLC method with mobile phase of acetonitrile: water (40:60) isocratically eluted for $30 \mathrm{~min}$.

Results: The chromatograms of the ethanol extract of C. mangga showed the presence of curcumin, bisdemethoxycurcumin, and demethoxycurcumin (DMC). Of all the curcuminoids content, DMC was the major component, corresponding to retention time at 9.96 min as compared to curcuminoid standard at $9.69 \mathrm{~min}$.

Conclusion: The results indicate that ethanol extract of C. mangga rhizomes contains DMC at the highest amount as compared to other curcuminoid compounds.

Keywords: Curcuma mangga, Curcumin, Bisdemethoxycurcumin, Demethoxycurcumin, Ultra-performance liquid chromatography.

(C) 2018 The Authors. Published by Innovare Academic Sciences Pvt Ltd. This is an open access article under the CC BY license (http://creativecommons. org/licenses/by/4. 0/) DOI: http://dx.doi.org/10.22159/ajpcr.2018.v11s1.26586

\section{INTRODUCTION}

Curcuma mangga is widely distributed in tropical countries such as Thailand, Malaysia, and Indonesia. The length and width of its leaves is ranging from $15-50 \mathrm{~cm}$ to $5-15 \mathrm{~cm}$, respectively. The rhizome is yellow in color and smell like mango [1]. C. mangga is a species of Curcuma which has been used as traditional medicine. It possesses a wide array of biological effects of $C$. mangga including nitric oxide inhibitory, analgesic, antifungal, anticancer, anti-inflammatory, and antioxidant activities [2-5].

C. mangga was found to contain various organic compounds including polyphenols, flavonoids, triterpenes, and sterols $[6,7]$. The plant was reported to have curcuminoid as its major components; these include curcumin, demethoxycurcumin (DMC), and bisdemethoxycurcumin (BDMC). Others Curcuma species also contain the major curcuminoid. Previous studies reported the presence of curcumin and the absence of BDMC in Curcuma xanthorrhiza, while BDMC was found in C. longa [8].

The observed pharmacological effects of Curcuma species have been attributed to curcuminoid content. Previous studies have shown various pharmacological effects of curcuminoids. Curcumin was reported to have antioxidant, anti-inflammatory, antimutagenic, and immunomodulatory activities [8]. In addition, C. mangga was reported to stimulate phagocytosis activity by in vivo study [9]. DMC and BDMC were found to inhibit nitric oxide production [3]. However, the precise amount of curcuminoid in C. mangga rhizomes was rarely reported.

In the present study, ethanol extract of $C$. mangga was investigated for its curcuminoid content including curcumin, DMC, and BDMC using ultra-performance liquid chromatography (UPLC). The results of this study may provide some insight of the major active component which contribute to the biological activities of $C$. mangga rhizomes.

\section{METHODS}

Chemicals and reagents

The chemicals used in this study were ethanol (SmartLab, Indonesia), acetonitrile HPLC grade (Merck, UK), and methanol HPLC grade
(Merck, UK). Curcumin $\geq 94 \%$ (curcuminoid content), $\geq 80 \%$ (curcumin) was obtained from Sigma-Aldrich (USA). Constituent determination was performed using ultra-performance liquid chromatography (UPLC) from Agilent Technologies (US), Millipore Millex PTFE membrane $(0.45 \mu \mathrm{m})$ (Whatman, UK), and C-18 column Eclipse Plus (100 $\mathrm{mm} \times 4.6 \mathrm{~mm}$ i.d., $3.5 \mu \mathrm{m}$ ) (Agilent Technologies, US). Detector used was DAD (Agilent 1290).

Plant collection

The C. mangga rhizomes were collected from Medan, Sumatera Utara, Indonesia. Then, the plant was authenticated in Herbarium Medanense, Universitas Sumatera Utara, Indonesia.

\section{Extraction procedure}

The rhizome materials were allowed to dry under shade at room temperature. The dried material $(500 \mathrm{~g})$ was ground and macerated and then subjected to extraction with ethanol at the ratio of 1:10 $(\mathrm{w} / \mathrm{v})$. The extraction was repeated twice on the residue. The filtrates were combined and the solvent was removed under reduced pressure to obtain extract of $C$. mangga $(38.4 \mathrm{~g}, 10.95 \% \mathrm{w} / \mathrm{w})$.

\section{UPLC analysis of the ethanol extract of $C$. mangga}

UPLC quantitative analysis of the ethanol extract of $C$. mangga was conducted by the modified method of Ang et al. [10]. The ethanol extract and the reference standards (quercetin) were dissolved in methanol to obtain 20 and $1 \mathrm{mg} / \mathrm{mL}$ solutions, respectively. The diluted solutions were filtered through Millipore Millex PTFE membrane $(0.45 \mu \mathrm{m})$ (Whatman, UK). UPLC qualitative and quantitative analyses of the filtered solutions were carried out using a C-18 column $(100 \mathrm{~mm} \times 4.6 \mathrm{~mm}$ i.d., $3.5 \mu \mathrm{m})$.

Table 1: Curcuminoid content of $C$. mangga rhizomes

\begin{tabular}{ll}
\hline Curcuminoid & Amount $(\boldsymbol{\mu g} / \mathbf{m L})$ \\
\hline Curcumin & 12.01 \\
DMC & 450.53 \\
BDMC & 329.45 \\
\hline
\end{tabular}

C. manga: Curcuma manga, DMC: Demethoxycurcumin,

BDMC: Bisdemethoxycurcumin 


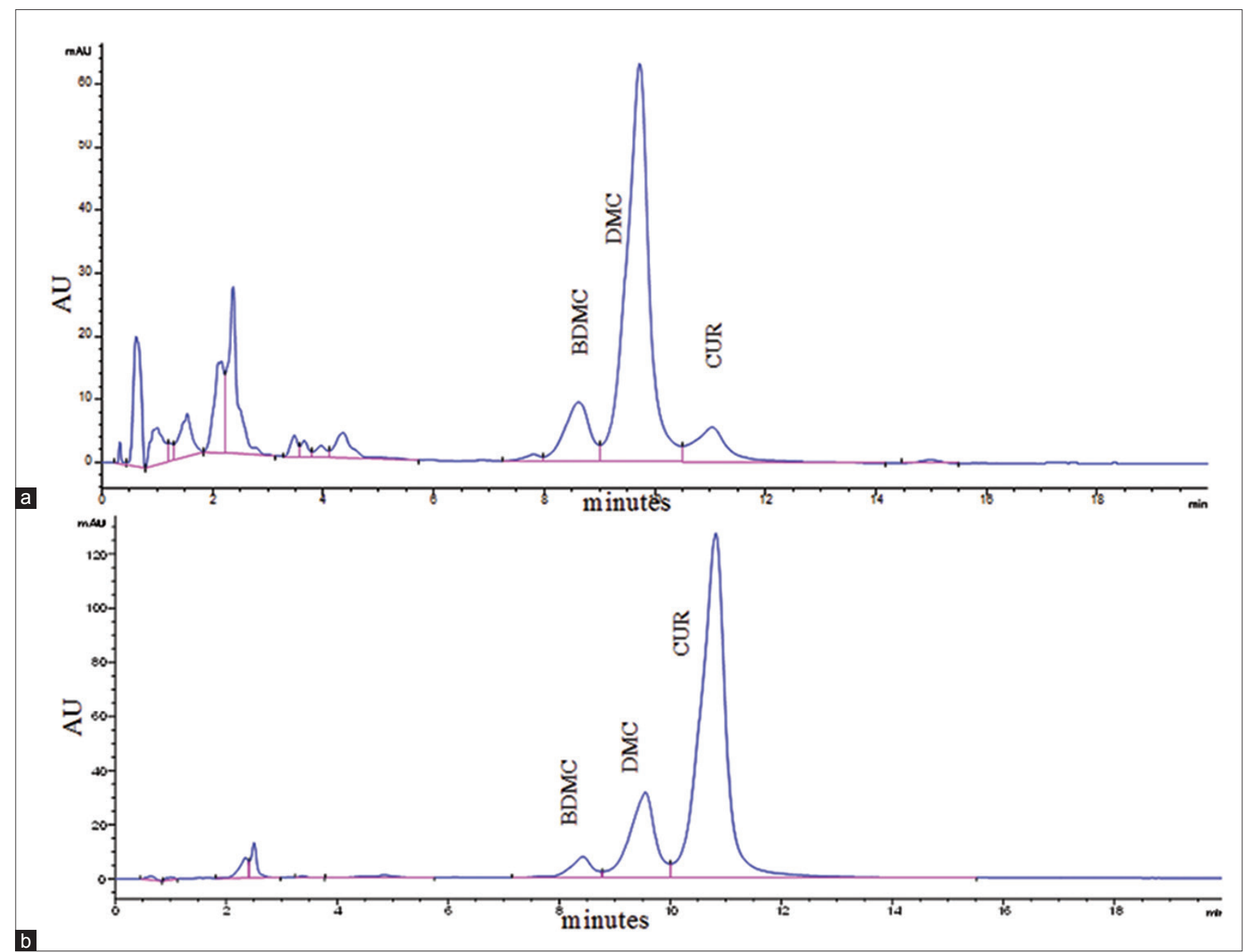

Fig. 1: Representative ultra-performance liquid chromatography chromatograms of (a) Curcuma mangga ethanol extract (b) reference standard mixture of curcumin, demethoxycurcumin, and bisdemethoxycurcumin RT 10.88, 9.62, and 8.50 min, respectively, detected at the wavelength of $370 \mathrm{~nm}$

Table 2: Precisions for interday and intraday repetitions for the quantitative detection of curcumin, DMC, and BDMC

\begin{tabular}{|c|c|c|c|c|c|c|c|c|c|c|c|c|}
\hline \multirow[t]{3}{*}{ Parameters } & \multicolumn{6}{|c|}{ Interassay precision } & \multicolumn{6}{|c|}{ Intra-assay precision } \\
\hline & \multicolumn{2}{|l|}{ CUR } & \multicolumn{2}{|c|}{ DMC } & \multicolumn{2}{|c|}{ BDMC } & \multicolumn{2}{|l|}{ CUR } & \multicolumn{2}{|l|}{ DMC } & \multicolumn{2}{|c|}{ BDMC } \\
\hline & RT & Peak area & RT & Peak area & RT & Peak area & RT & Peak area & RT & Peak area & RT & Peak area \\
\hline Mean & 10.88 & 4004.8 & 9.62 & 994.7 & 8.5 & 208.8 & 10.94 & 3551 & 9.68 & 896.6 & 8.56 & 172.7 \\
\hline SD & 0.06 & 453.65 & 0.06 & 93.29 & 0.06 & 32.19 & 0.01 & 17.6 & 0.01 & 4.65 & 0.01 & 0.91 \\
\hline$\%$ RSD & 0.56 & 11.33 & 0.67 & 9.38 & 0.76 & 15.42 & 0.09 & 0.49 & 0.17 & 0.52 & 0.17 & 0.53 \\
\hline
\end{tabular}

DMC: Demethoxycurcumin, BDMC: Bisdemethoxycurcumin, SD: Standard deviation, RSD: Relative standard deviation, RT: Retention time, CUR: Curcumin

The mobile phase were acetonitrile (40\%): water (60\%) and eluted isocratically for $5 \mathrm{~min}$ at a flow rate of $1.3 \mathrm{~mL} / \mathrm{min}$. Detector used was DAD (Agilent 1290), wavelength: $370 \mathrm{~nm}$. Quercetin was identified by comparing the ultraviolet-visible spectra and retention time of the peak and those of the standard. Quantification of the compounds in the extract was carried out by plotting calibration curves of standard solution with four different concentrations $(100,50,25,12.5$, and $6.25 \mu \mathrm{g} / \mathrm{mL})$ versus the areas under the peaks.

\section{Validation procedure}

Linearity, precision, limits of quantification (LOQ), and limits of detection (LOD) were determined to validate the reversed-phase UPLC method. The precision of the method was determined by interassay and intra-assay validation. Linearity was determined by linear calibration analysis while the calibration curves were used to calculate the correlation coefficient (r2). LOQ and LOD were calculated from the RSD and slope (S) of the calibration curves using equations,

$\mathrm{LOQ}=3.3 \times(\mathrm{RSD} / \mathrm{S})$

$\mathrm{LOQ}=10 \times(\mathrm{RSD} / \mathrm{S})$

\section{RESULTS AND DISCUSSION}

Quantitative analysis of the ethanol extract of $C$. mangga by UPLC Curcumin was in a mixture with DMC and BDMC as compared with previous studies [10]. The chromatogram of the ethanol extract of C. mangga showed major peak of curcuminoid, which include curcumin, DMC, and BDMC with retention times at $\min 11.19,9.96$, and 
8.44 min, respectively. The peak was compared to reference standards curcuminoid with retention times at 10.88, 9.62, and $8.50 \mathrm{~min}$, respectively (Fig. 1). Table 1 summarizes that DMC $(450 \mu \mathrm{g} / \mathrm{mL})$ was the most abundant compound as compared to other curcuminoid. The result was in agreement with previous study which was able to isolate DMC from C. mangga rhizomes, indicating the high amount of DMC in C. mangga [11].

\section{Method validation}

Calibration curves plotted were linear over the concentration range $100-6.25 \mu \mathrm{g} / \mathrm{mL}$ with a correlation coefficient $\left(\mathrm{r}^{2}\right)$ of $0.998,0.996$, and 0.980 for curcumin, DMC, and BDMC, respectively. These \%RSD values of intra-assay precision of peak area and retention time demonstrated the reproducibility of the results (Table 2). LOD of curcumin, DMC, and BDMC were found to be $1.14,20.24$, and $103.29 \mu \mathrm{g} / \mathrm{mL}$, respectively. Meanwhile, LOQ of curcumin, DMC, and BDMC were found to be 3.44, 59.12, and $312.99 \mu \mathrm{g} / \mathrm{mL}$, respectively.

\section{CONCLUSION}

The HPLC analysis methods proposed in this study enable identification and quantification of major curcuminoids in the ethanol extracts of $C$. mangga. These include curcumin, BDMC, and DMC. Of all the curcuminoid identified, DMC presents in highest amount in C. mangga rhizomes. However, further studies using various techniques are required to elucidate others constituent.

\section{ACKNOWLEDGMENT}

This work was supported by University of Sumatera Utara through TALENTA research grant scheme with grant number of 175/UN5.2.3.1/ PPM/KP-TALENTA USU/2017.

\section{REFERENCES}

1. Ismail S. Traditional Vegetables. Bangi: National University of Malaysia; 2000

2. Hong GW, Hong SL, Lee GS, Yaacob H, Malek SN. Non-aqueous extracts of Curcuma mangga rhizomes induced cell death in human colorectal adenocarcinoma cell line (HT29) via induction of apoptosis and cell cycle arrest at G0/G1 phase. Asian Pac J Trop Med 2016;9:8- 18.

3. Ruangsang P, Tewtrakul S, Reanmongkol W. Evaluation of the analgesic and anti-inflammatory activities of Curcuma mangga Val and Zijp rhizomes. J Nat Med 2010;64:36.

4. Karsono AH, Tandrasasmita OM, Tjandrawinata RR. Molecular effects of bioactive fraction of Curcuma mangga (DLBS4847) as a downregulator of $5 \alpha$-reductase activity pathways in prostatic epithelial cells. Cancer Manag Res 2014;6:267-78.

5. Jantan I, Yassin MA, Chin CB, Chen LL, Sim NL. Anti-fungal activity of the essential oils of nine Zingiberaceae species. Pharm Biol 2003:41:392-7.

6. Abas F, Lajis NH, Khozirah S, Israf DA, Jhonson S, Kalsom YU, et al. Labdane diterpene glucoside from the rhizomes of Curcuma mangga. J Nat Prod 2005;68:1090-3.

7. Malek SN, Lee GS, Hong SL, Yaacob H, Wahab NA, Weber JF, et al. Phytochemical and cytotoxic investigations of Curcuma mangga rhizomes. Molecules 2011;16:4539-48.

8. Erupoean Medicines Agency (EMA). Assessment report on Curcuma xanthorrhiza Roxb. (C. xanthorrhiza D. dietrich). rhizoma. 2012; EMA/HMPC/604598/2012.

9. Yuandani, Suwarso E. Immunomodulatory effects of ethanol extract of Curcuma mangga rhizomes in mice. Asian J Pharm Clin Res 2017; $10: 148-50$.

10. Ang LF, Yam MF, Fung YT, Kiang PH, Darwin Y. HPLC method for simaltaneous quantitative detection of quercetin and curcuminoids in traditional chinese medicines. J Pharm 2014;17:36-49.

11. Kaewkroek, K. Chatchai W, Supinya S. Nitric oxide inhibitory substances from Curcuma mangga rhizomes. Songklanakarin J Sci Tech 2009;31:293-7. 